\title{
Enhancing the Strength Properties of Self-Compacting Concrete with Fiber Reinforcement
}

\author{
Sajan Sharma, Gurvinder Singh
}

\begin{abstract}
Self-compacting concrete is one that is flow able by its own. The SCC is suitable for placing in dense reinforcement structures. It is a new generation performance concrete known for its outstanding deformity and high resistance to bleeding. The concrete is frail material which is comparatively tough in compression but fragile in tension. The tensile strength of concrete is improved by addition of fibers in the concrete mix. The addition of such fibers has negative consequence on the workability of concrete. Various types of fibers are used in concrete to provide the higher flexural strength and better tensile strength. In this research steel fibers are used to provide a better strength as compared with normal reinforced concrete. Steel fiber in SCC significantly improves its flexural strength, improved tensile properties, reduce cracking and improve durability. In this research the investigation of steel fiber in SCC to enhance the strength properties of SCC. The objective of the study was to determine different properties of SCC with steel fiber at different proportions. The experimental investigation was took on the freshly mixed and hardened properties of SCC of various mix with the different variations of fiber $0.25 \%, 0.50 \%, 0.75 \%$ and $1 \%$ by using Viscosity Modified Agent (VMA) 1.5\% of cement material by using M25 grade of concrete. In this research a series of tests were carried out for workability like slump cone test, $U$ funnel, $V$ funnel, $L$ box test on SCC to check freshly mix properties like flow-ability, filling-ability, and passing-ability and hardened properties like compressive strength, split-tensile strength and flexural strength respectively and test were conducted at the age of 7Days, 14Days, 28Days on the SCC. The advantage of adding steel fiber in self-compacting concrete is that it enhances its overall strength.
\end{abstract}

Index Terms: SCC- Self Compacting Concrete, $\mathrm{KN}$ - Kilo Newton, KG- Kilogram, M-Meter, CTM-Compression Testing Machine.

\section{INTRODUCTION}

Self-Compacting Concrete (SCC) is that which doesn't need shaking for positioning and packing. It is flow-able by gravity, filling formwork completely and obtaining full packing, even in the dense steel work. In structural members with dense steel work it fills all voids and gaps completely. SCC flows similar to viscous liquid and has almost a flat concrete level of placing. The hardened concrete is impenetrable, cognate $\&$ has the similar properties and endurance as shaked/vibrated concrete. Self-compacting concrete broaden the possibility of use of different mineral

Revised Manuscript Received on July 26, 2019.

*Correspondence Author

Sajan Sharma*, Mtech Civil Structure, Kurukshetra University, Ambala, India.

Gurvinder Singh., Mtech Civil Structure, D.A.V. University, Jalandher, India.

(c) The Authors. Published by Blue Eyes Intelligence Engineering and Sciences Publication (BEIESP). This is an open access article under the CC BY-NC-ND license (http://creativecommons.org/licenses/by-nc-nd/4.0/) by-products in its composition \& its mechanical properties, as tested by compressive, tensile and shear strength, is increased. On the other side, the use high range water reducers or super- plasticizers, improves the flow-ability \& quality of the concrete. Practically, various types of structure constructions are possible with this concrete. The use of SCC not only lessens the construction time but at the same time gives quality and endurance to concrete. SCC faster the placing and lessens finishing time, improved productivity. SCC mixture contains super plasticizer, low W/C ratio \& aggregate providing for high strength \& earlier de-shuttering. SCC of high flow-ability and segregation resistance is achieved by using a high Portland cement content, viscosity modifying additives (VMA) \& super plasticizer.

\section{MATERIAL MIX \& DESIGN}

\section{A. Materials}

Ordinary Portland Cement (43 Grade) of brand Shree Ultra Cements was used in this study. The cement considered for the test confirmed the relevant Indian standard code of practice BIS 8112:2013. Specific Gravity test conducted with specific gravity bottle on cement. Specific Gravity of the cement tested is 3.12. The fly ash class F confirming BIS 3812 (Part 2): 2003 was used in this project was grey in color, having specific gravity 2.08 by using specific gravity bottle. Usually the coarse aggregates as per BIS 383:1970 occupy $44 \%-52 \%$ of the volume of self-compacting concrete have an important factor on its properties. These are granular material, extracted generally from natural rocks. Coarse Aggregates used in this work were crushers of nominal Size $20 \mathrm{~mm}$. SCC mainly contains higher amount of fine aggregates than coarse aggregates. Fine Aggregates are kept $48-56 \%$ of total aggregates by weight. For this project fine aggregate of river based sand. BROCRETE SCC from FAIR MATE was used in the project work as chemical admixture. It can be based on modified carboxylic ether, chloride content $<0.2 \%$ as per IS: $9103: 1999$ and ph. value 6 to 8 . Normal dosage is about $0.6 \%$ to $1.5 \%$ by weight of cementious material and color was amber clear liquid. Steel fibers are produced by cutting steel wires into shreds. Steel fiber concrete is generally an economical and easier to use a form of rebar reinforced concrete. It can improve the tensile properties and controlling cracks in concrete material. 
It is manufactured of low carbon cold down steel wires crinkle shape and manufactured in accordance with ASTM A820 type I. Steel fiber widely improve physical properties of concrete. It is easy to use \& no special instrument is necessary in the process of blending and pouring.

\section{B. Mix Proportion}

There is no definitive method for SCC mix design \& in many institutions, admixtures; ready-mixed plants, pre cast \& concreting plants have invented their own mix ratio methods. There is various mix design methods proposed to prepare self compacting concrete. EFNARC specifications can be used for trial mix preparing self compacting concrete.

Initial Mix Design Proportions

\begin{tabular}{|c|c|}
\hline CONSTITUENTS & AMOUNT(KG/M $\left.\mathbf{M}^{\mathbf{3}}\right)$ \\
\hline CEMENT & 330 \\
\hline FINE AGGREGATES & 795 \\
\hline COARSE AGGREGATE & 1035 \\
\hline FLY ASH & 95 \\
\hline WATER & 191 \\
\hline
\end{tabular}

\section{TESTS}

a) Slump Test. The slump test is used in measurement of the mean diameter of the concrete mix spread on a base plate after lifting the slump cone without packing. In this test the flow-ability of the SCC mixture is tested. The required minimum slump flow for the test is $80.0 \mathrm{~cm}$. While the slump flow rests the viscosity of mixture is calculated by noticing the time taken to reach the spread of diameter of $50.0 \mathrm{~cm}$ from the time slump cone is lifted up. There is no resistance offered to the freely flowing SCC mixture.

\section{Slump Test}

b) V-Funnel Test. This test was introduced in Japan and used by Ozawa. This test is used to measure the filling ability of the concrete. The funnel is filled approximately 14 liters of concrete and the time consumed by concrete to flow through

\begin{tabular}{|c|c|c|}
\hline $\begin{array}{c}\text { MIX } \\
\text { DESIGNATION }\end{array}$ & $\begin{array}{c}\text { \% OF } \\
\text { FIBER }\end{array}$ & $\begin{array}{c}\text { SLUMP FLOW IN } \\
\text { (MM) }\end{array}$ \\
\hline$\dot{\text { S0 }}$ & NIL & 81 \\
\hline$\dot{\text { S} 01}$ & 0.25 & 80 \\
\hline$\dot{\text { S} 02}$ & 0.50 & 79 \\
\hline$\dot{\text { S} 03}$ & 0.75 & 76 \\
\hline$\dot{\text { S}} 04$ & 1.0 & 73 \\
\hline
\end{tabular}

the apparatus is measured. It should between 8.0-12.0 sec. This test is designed to calculate the flow-ability; the test result is influenced by concrete mix properties other than flow-ability alone. High flow time can be correlated with low deformability because of high paste viscosity \& with high inter-particle resistance. On the other hand the apparatus is simple, the side effect due to the angle of the funnel \& the side wall effect on the flow-ability of concrete are not clearly defined.

\section{A. Testing of SCC in Fresh State.}

\section{V-Funnel Test}

c) U-Box Test. The U box test is done to calculate both filling \& passing of SCC. This test can also be done to determine the resistance of SCC to segregate by correlating test results from

\begin{tabular}{|c|c|}
\hline MiX DESIGNATION & FILLING TIME IN (SEC) \\
\hline$\dot{\mathrm{S}} 0$ & 7.9 \\
\hline$\dot{\mathrm{S}} 01$ & 8.1 \\
\hline$\dot{\mathrm{S}} 02$ & 8.5 \\
\hline$\dot{\mathrm{S}} 03$ & 8.9 \\
\hline$\dot{\mathrm{S}} 04$ & 8.8 \\
\hline
\end{tabular}

two different portions of mix. It should be $0.0-30.0 \mathrm{~mm}$ as per EFNARC specifications.

U-Box Test

\begin{tabular}{|c|c|}
\hline MiX DeSignATION & PASSING HeIGHT IN (MM) \\
\hline$\dot{\mathrm{S} 0}$ & 7.8 \\
\hline$\dot{\mathrm{S}} 01$ & 8.2 \\
\hline$\dot{\mathrm{S}} 02$ & 8.4 \\
\hline$\dot{\mathrm{S}} 03$ & 8.7 \\
\hline$\dot{\mathrm{S}} 04$ & 8.9 \\
\hline
\end{tabular}

d) L-Box Test. The L box test is done to calculate the passing ability of SCC. In this test we measure the height of freshly mixed SCC after letting it pass through the specified gaps of steel bars \& flowing up to a defined distance. It should be 0.5-1.0 as per EFNARC specification.

\section{L-Box Test}

\section{B. Testing of SCC in Hardened State.}

a) Compressive Strength Test. Specimen Cubes of $150 \mathrm{X}$ 150 X $150 \mathrm{~mm}$ are used to determine compressive strength of

\begin{tabular}{|c|c|}
\hline MiX DESIGNATION & BLOCKING RATIO \\
\hline$\dot{\text { S}} 0$ & 0.60 \\
\hline$\dot{\mathrm{S}} 01$ & 0.601 \\
\hline$\dot{\mathrm{S}} 02$ & 0.805 \\
\hline$\dot{\mathrm{S}} 03$ & 0.70 \\
\hline$\dot{\mathrm{S}} 04$ & 0.90 \\
\hline
\end{tabular}

concrete. The specimens are tested according to IS 516-1959. Testing is performed on $2000 \mathrm{KN}$ capacity compression testing machine (CTM) by the following general procedure. The casted cubes taken out of the water tank after the necessary period of curing, wiped off the excessive moisture to make the cube surface dry. Later it is placed on the CTM in such a way that its face is perpendicular to the direction of load is on the bearing surfaces \& load is applied centrally. The maximum load at which failure of cube occur is noticed. The test on the cube is repeated on three cube specimens for 7 Days, 14 Days and 28 Days each.

Three cube specimens are tested each time and the average value is taken as the mean strength of cubes. 
Variation of Strength

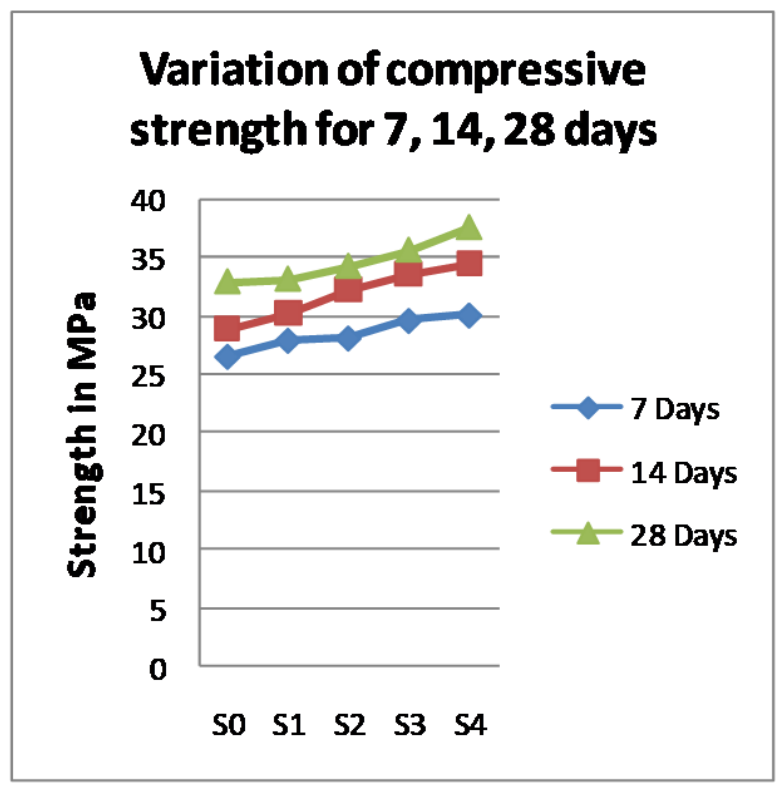

b) Rebound Hammer Test. Rebound Hammer test is carried on the cubes to check the compressive strength with the help of Rebound hammer. Rebound hammer test is done on hardened surface becomes most popular worldwide for in-situ concrete non-destructive testing. Testing is done for 7 Days, 14 Days and 28 Days

\section{Variation of Strength}

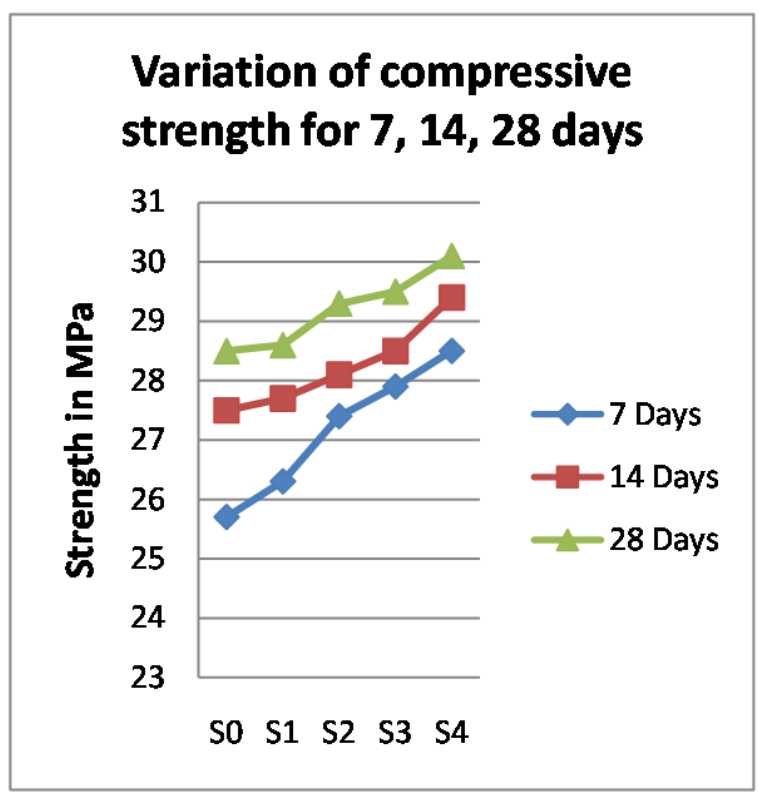

c) Split Tensile Strength Test. The test is performed by testing a cylindrical concrete specimen of diameter $150 \mathrm{~mm}$ and $300 \mathrm{~mm}$ long horizontally between the loading plates of a compression testing machine of capacity $2000 \mathrm{KN}$ and load is applied till failure of the concrete specimen. Testing is done for 7 Days, 14 Days and 28 Days. Per BIS5816: 1999.

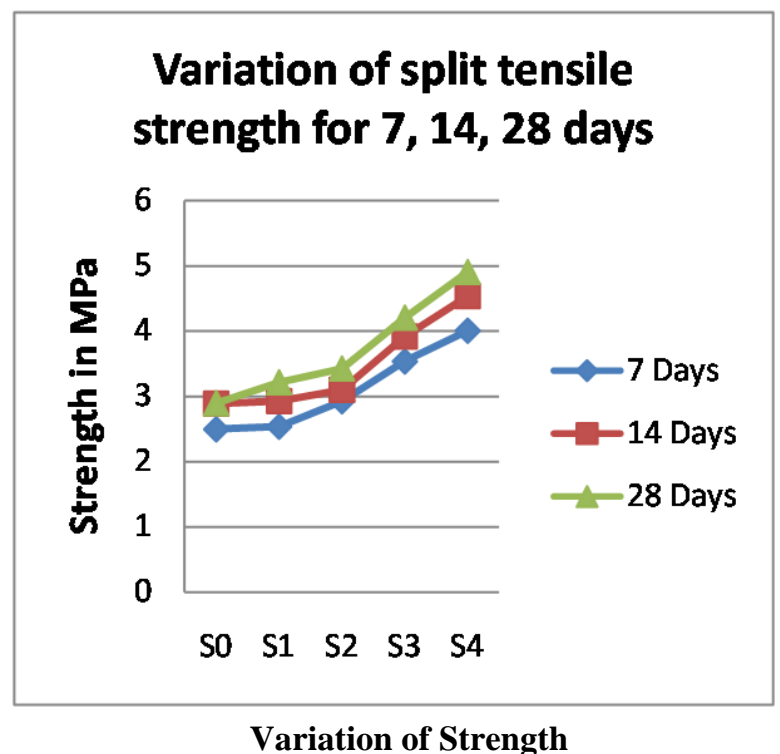

d) Flexural Strength Test. The test is carried out on standard beams of $500 \mathrm{~mm}$ long, $100 \mathrm{~mm}$ wide and $100 \mathrm{~mm}$ deep. It is placed by long side horizontally in the flexural test machine capacity of $2000 \mathrm{KN}$ and load was applied until the failure of sample. Test is done for 7Days, 14Days and 28Days as per BIS5816:1999

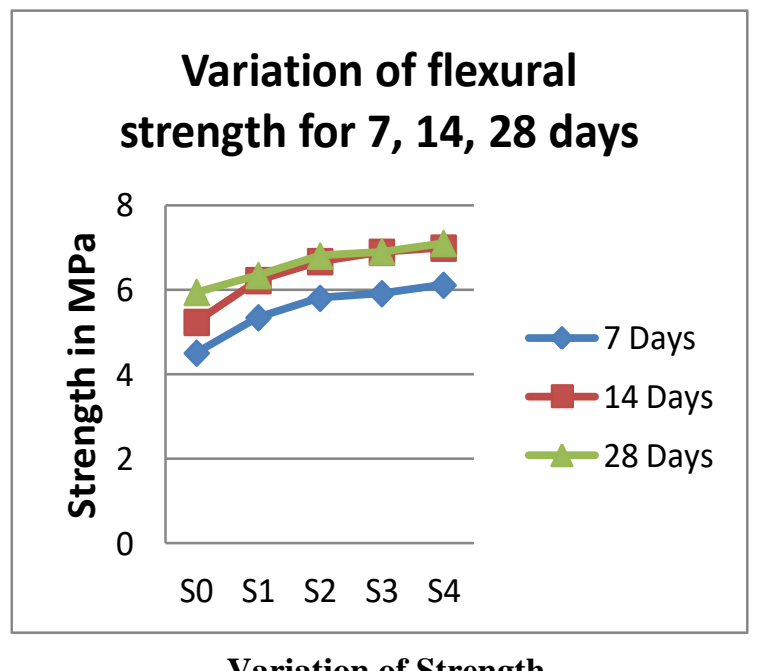

Variation of Strength

IV. CONCLUSION

After all the experimental work the conclusion are given as under:

- When the \% of steel fiber is increased the flow ability of concrete mix decrease due to the irregular shape of steel fibers.

- Addition of steel fiber in concrete has very minor effect on the compressive strength of concrete. By adding different variation of fiber $(0.25 \%, 0.50 \%$, $0.75 \%, 1.0 \%$ ) in concrete mix increase the compressive strength for 7 days - 5\%, 6\%, 11\%, 12\%, 14days - $4 \%$, $11 \%, 16 \%$, 20\%, 28days - 2\%, $4 \%, 8 \%, 14 \%$. 


\section{Enhancing the Strength Properties of Self-Compacting Concrete with Fiber Reinforcement}

- Concrete is weak in tension so it has low tensile strength so due to addition of steel fiber in concrete it increase tensile strength. By adding different variation of fiber $(0.25 \%, 0.50 \%, 0.75 \%, 1.0 \%)$ in concrete mix split tensile strength for 7days - 2\%, 17\%, 41\%, 60\%, 14days - 2\%, 7\%, 35\%, 57\%, 28days - 11\%, 18\%, 45\%, $69 \%$.

- Addition of steel fiber in concrete increase the flexural strength. By adding different variations of steel fiber $(0.25 \%, 0.50 \%, 0.75 \%, 1.0 \%)$ in concrete mix flexural strength for 7 days - 18\%, 28\%, 31\%, 35\%, 14 days - 18\%, 27\%, 31\%, 33\%, 28days - 6\%, $14 \%$, $15 \%, 19 \%$.

- Ratio of difference in compressive strength by CTM or by rebound hammer is varying in between 1.03 to 1.24 .

\section{REFERENCES}

1. Parvathy Sunil A. (2017) "Experimental study on the shear behavior of basalt fiber reinforced concrete beams with steel and BFRP stirrups".

2. AfifuddinMohammad (2016) "Shear behaviour of fiber foam reinforced concrete beams". Proscenia engineering 171 (2017) 994-1001.

3. Ahmed Gulzar (2016) "Use of steel fiber as reinforcement material with concrete" ISSN 2278-5299.

4. ChakarabortyJayanta (2016) "International journal of shear strength of self-compaction concrete deep beam" E-ISSN 0976-3945.

5. VandewalleLucie (2016) "Shearbehaviour of steel fiber reinforced self-compacting".

6. "International journal of self compacting fiber reinforcement" by ChakrabortyJayanta (2016) ISSN 2348-8352.

7. Zagon Raul (2015) "Shearbehavior of UHPC concrete beams proscenia technology" 22(2016)122-126.

8. KhaledS.Ragab (2014) "Behavior of steel fiber reinforced high strength self compacting concrete beams under combined bending and torsion" ISSN 0976-4399.

9. Dr. Mrs. S.A. "Performance of steel fiber reinforced self compacting concrete". International journal of computational engineering research (ijceronline) Vol- 2 Issue.4. (2014).

10. ShahanaSheril P.T "Self compacting concrete using steel fiber". International journal of engineering and research. (IJERT) (2013).

11. Mueller Torstein(2013)“Investigation shear transfer between vibrated and self-compacting concrete in reinforced concrete" construction proscenia engineering 57(2013)398-406.

12. Vinayak B. "Flexural behavior of self compacting high strength fiber reinforced concrete" (2013). International journal of engineering research and applications.

13. H Okamura and M Ochi (2013) "Self compacting concrete" Journal of advanced concrete technology.

14. AmbilyP.S (2012) "Experimental studies on shear behaviour of reinforced geo-polymer concrete thin webbed $\mathrm{T}$ - beam with and without fiber" ISSN 0976-4399.

15. Milind V. Mohod"Performance of steel fiber reinforced concrete", IJCS ISSN (2012).

16. T.H.K Kang \&W.Kim (2010) "Shearbehavior of steel fiber reinforced lightweight concrete beams". ISBN 978-89-5708-182-2.

17. Shah D.L (2010)"Evaluation of shear strength of self compacting concrete deep beam". E-ISSN 0976-3945.

18. P SriniasaRao G K "Flexural behavior of reinforced concrete beams using self compacting concrete". Conference on our world in concrete and structures. (2009).

19. Indian Standard Code of Practice "Concrete Mix Proportioning Guidelines IS 10262:2009.

20. Thomas T.C Hsu (2008) "Shear behaviour of prestressed beams with steel fiber self compacting".

21. Ganesan.N"Strength and behavior of steel fiber reinforced self compacting concrete in flexure". International conference on advance in concrete (2005)

22. Rui D. Neves (2005) "Compressive strength of steel fiber reinforced concrete".

23. EFNARC (2005) the "European guidelines for self compacting concrete production, specifications and uses".
24. M L Gambhir Concrete Technology theory and practice Mc Grew Hill publication. $5^{\text {th }}$ edition (2003)

25. "ACI journal of shear strength of reinforced concrete" Part 1 by Rahal in (2000).

26. Nagaraj T.S. (2002) “Compressive study of steel fiber concrete”. ACI material journal.

27. Oh B.H. (2002) "Flexural analysis of reinforced concrete beams col joints." (ASCE).

28. ACE Committee 544, State-of-the-Art Report on "Fiber Reinforced Concrete", ACI concrete international, 4(5):9-30(May,2000).

29. Naaman, A.E., "Fiber Reinforced for concrete", ACI concrete international, 7(3):21-25(March, 2000).

\section{AUTHORS PROFILE}

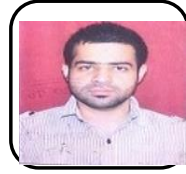

Sajan Sharma, Mtech Civil Structure, Btech Civil Engg. , Diploma Civil Engg. With Hons Email Id-sajansharma2@gmail.com

Gurvinder Singh , Mtech Civil Structure , Btech Civil Engg. 